\title{
Методичний підхід до визначення раціонального варіанту модернізації функціональних систем зразків зенітного ракетного озброєння
}

\author{
Павло Опенько * 1 А; Владислав Кобзєв ${ }^{2 \text { в; Вадим Васильєв }}{ }^{3 \text { в; }}$ \\ Олег Угринович 4 А; Володимир Дяченко 5 с \\ А Національний університет оборони України імені Івана Черняховського, м. Київ, Україна

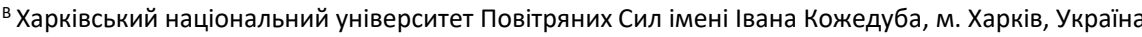 \\ с Військова академія, м. Одеса, Україна
}

Received: December 5, 2021 | Revised: December 17, 2021 | Accepted: December 30, 2021

DOI: $10.33445 /$ sds.2021.11.6.10

\begin{abstract}
Анотація
Результати досліджень, що опубліковано в статті, будуть корисні для фахівців логістичного забезпечення, які займаються питаннями організації експлуатації та відновлення озброєння та військової техніки. У статті розглядається методичний підхід щодо обгрунтування раціонального варіанта модернізації зенітного ракетного озброєння 3 урахуванням зміни властивостей елементів радіоелектронної апаратури і можливостей щодо створення елементів функціональних систем на сучасній елементній базі. Проаналізовані існуючі у науково-технічній літературі публікації, присвячені питанням морального старіння складних технічних систем різного призначення, в тому числі стану елементної бази радіоелектронної апаратури зразків зенітного ракетного озброєння, встановлено, що завдання, пов'язані з модернізацією функціональних систем зразків зенітного ракетного озброєння з урахуванням зміни властивостей елементів обладнання, використовуючи при цьому сучасну елементну базу, на даний час $\epsilon$ невирішеним, що дозволило визначити наукове завдання, що полягає в подальшому розвитку науковометодичного апарату вибору раціонального варіанту модернізації зенітного ракетного озброєння з урахуванням зміни властивостей елементів радіоелектронної апаратури i можливостей щодо створення елементів функціональних систем на сучасній елементній базі. Обґрунтовано вибір доцільного варіанту модернізації функціональних систем зразків зенітного ракетного озброєння з декількох альтернативних як за рівнем глибини модернізації, так за використовуваною елементною базою з використання методичного апарату, в якості якого виступатиме запропонований методичний підхід до обґрунтування раціонального варіанту модернізації функціональних систем зі створенням їх елементів на сучасній елементній базі. Показано, що в умовах, що склалися, доцільною $\epsilon$ розробка модернізованих систем (блоків, субблоків) зразків зенітного ракетного озброєння та їх складових частин на базі імпортованих елементів з урахуванням додаткових організаційних та технічних заходів щодо забезпечення надійності у визначених умовах експлуатації. Наведено, що для вирішення поставленого завдання потрібне обґрунтування та вибір показників та критерію ефективності, використання яких дозволить описати кожен 3 варіантів модернізації зі створенням елементу функціональних систем на сучасній елементній базі, в тому числі матеріальні та часові витрати, та порівняти їх між собою.
\end{abstract}

\footnotetext{
1 * Corresponding author: к.тех.н., старший дослідник, начальник науково-дослідного відділу, e-mail: pavel.openko@ukr.net, ORCID: 0000-0001-77775101

2 к.т.н., с.н.с., старший науковий співробітник науково-дослідного відділу, e-mail: vladiskob@ukr.net, ORCID: 0000-0002-0954-8887

${ }^{3}$ к.т.н., с.н.с., старший науковий співробітник науково-дослідного відділу, e-mail: vva74@ukr.net, ORCID: 0000-0001-5802-9111

${ }^{4}$ к.військ.н., доцент, професор кафедри, e-mail: olegenya999@gmail.com, ORCID: 0000-0001-6644-7620

${ }^{5}$ к. військ. н., начальник кафедри, e-mail: gw7388@gmail.com, ORCID: 0000-0002-2904-8337
} 
Ключові слова: зенітне ракетне озброєння, моральне старіння, функціональна система, елементна база, модернізація.

\section{Постановка проблеми}

Сучасні зразки зенітного ракетного озброєння (ЗРО) належать до одних 3 найбільш складних і дорогих виробів озброєння та військової техніки [1]. Виходячи з цього, більшість країн світу для вирішення завдань протиповітряної (протиракетної) оборони намагається використовувати ресурсний потенціал існуючого парку ЗРО до досягнення ними граничних меж ресурсних показників, до яких можлива їх безпечна експлуатація.

На даний час основними шляхами забезпечення справності та безпечності експлуатації зразків ЗРО $\epsilon$ виконання ремонтів, продовження призначених термінів служби (ресурсів), впровадження адаптивних стратегій технічного обслуговування і ремонту (наприклад, експлуатація за технічним станом), а також модернізація за критерієм "ефективністьвартість" [2, 3]. Реалізація цих заходів повинна враховувати фактор морального старіння [4] і спиратися на відповідний науково-методичний апарат прогнозування динаміки зміни технічного стану та надійності ЗРО [5]. При цьому досвід експлуатації радіоелектронної апаратури зразків ЗРО свідчить про усталену тенденцію випередження морального старіння елементної бази апаратури у порівнянні 3 моральним старінням цих зразків озброєння. Життєвий цикл багатьох зразків ЗРО значно перевершує життєвий цикл або періодичність зміни елементної бази, на якій реалізована їх радіоелектронна апаратура. За час із появи перших зразків ЗРО елементна база пройшла п'ять поколінь розвитку, починаючи від електровакуумних приладів першого покоління до надвеликих інтегральних мікросхем (HBIC) і систем на кристалі (СНК) п'ятого покоління [6]. Отже, сучасний рівень напівпровідникової технології дозволяє здійснити якісно нову реалізацію раніше створених елементів функціональних систем (ФС) на елементній базі четвертого або п'ятого покоління. Зазначена реалізація передбачає інтеграцію великої кількості мікросхем і дискретних елементів в один кристал. Саме тому розгляд питань, пов'язаних з модернізацією ФС засобів ЗРО 3 використанням сучасної елементної бази $€$ актуальним.

\section{Аналіз останніх досліджень та публікацій}

Питанням дослідження морального старіння складних технічних систем різного призначення, в тому числі стану елементної бази радіоелектронної апаратури зразків 3РО, присвячено велика кількість публікацій [7-16].

Так, в [7-9] наведені форми морального старіння складних технічних систем, до яких належать зразки ЗРО. Зазначено, що економічна форма морального старіння (або моральне старіння першого роду) має місце у ситуації, коли на ринку з'являються нові більш ефективніші зразки ЗРО, внаслідок чого виробництво і використання застарілої техніки стає економічно недоцільним. Функціональна форма морального старіння (або моральне старіння другого роду) має місце у ситуації, коли бойові і функціональні можливості існуючих зразків ЗРО не задовольняють вимогам боротьби з новими типами засобів повітряного нападу противника. Внаслідок функціонального старіння ЗРО з часом переходить в категорію застарілого озброєння. Крім того, в роботах [10-13] стосовно складних технічних систем запропоновано розглядати моральне старіння третього роду, яка пов'язана 3 деградацією можливостей відновлення працездатності ЗРО із-за вичерпання запасних частин, інструментів та приладдя (ЗІП), неможливості поповнення ЗІП в результаті зняття комплектуючих виробів 3 виробництва, застосування застарілих 
технологій ремонту та відсутності фахівців $з$ ремонту обладнання. Виходячи 3 викладеного, в [14] під моральним старінням третього роду розуміється деградація (стійке зниження) можливостей відновлення здатності ЗРО вирішувати бойові завдання, що покладаються на нього, з необхідними характеристиками якості в умовах виникнення відмов апаратури і обладнання. В той же час в публікаціях $[15,16]$ відзначається, що в країнах колишнього Радянського Союзу склалася проблемна Постановка завдання

Вплив внутрішніх та зовнішніх факторів потребує постійної відповідності тактикотехнічних та експлуатаційно-технічних характеристик зразків існуючого парку ЗРО сучасним вимогам. Саме тому виникає необхідність наукового обгрунтування вибору найбільш раціонального варіанта модернізації ЗРО з точки зору реалізації найбільш доцільних варіантів створення елементів ФС на сучасній елементній базі.

Таким чином, наукове завдання полягає у подальшому розвитку науково-методичного $\begin{array}{lccr}\text { ситуація } 3 & \text { елементною } & \text { базою } \\ \text { радіоелектронної } & \text { апаратури } & \text { складних }\end{array}$ технічних систем військового призначення, що створило ряд складних задач при організації їх експлуатації і модернізації.

Таким чином, проведений аналіз свідчить, що завдання, пов'язані з модернізацією ФС зразків ЗРО 3 урахуванням зміни властивостей елементів обладнання, використовуючи при цьому сучасну елементну базу, є невирішеним, а тема статті актуальною.

апарату вибору раціонального варіанта модернізації ЗРО 3 урахуванням зміни властивостей елементів радіоелектронної апаратури і можливостей щодо створення елементів ФС на сучасній елементній базі.

Метою статті $\epsilon$ викладення методичного підходу щодо обґрунтування раціонального варіанта модернізації ЗРО з урахуванням зміни властивостей елементів радіоелектронної апаратури і можливостей щодо створення елементів ФС на сучасній елементній базі.

\section{Виклад основного матеріалу}

Радіоелектронна апаратура зразків ЗРО, що експлуатуються в Збройних Силах України в даний час, реалізована на елементній базі третього покоління, яка включає інтегральні мікросхеми малого і середнього ступеню інтеграції. Аналіз складу і конструктивного виконання апаратури засобів зразків ЗРО показує, що її функціонально закінчені вузли конструктивно реалізовані у вигляді друкованих плат, чарунок та блоків з різною кількістю універсальних і спеціалізованих мікросхем та окремих компонентів. Застосовані в цих зразках озброєння радіоелементи та елементи цифрової логіки серійно випускалися в Радянському Союзі у останній чверті XX століття та в цілому відповідали розвитку елементної бази того часу. Натепер, більшість з цих базових елементів вже не випускаються промисловістю, а майже всі підприємства, які їх випускали, припинили своє існування. Відновлення випуску цих елементів малоймовірне через велику вартість відновлення технологічних процесів (відсутність відповідного обладнання, документації, кадрів), економічну недоцільність розгортання вартісних виробництв для випуску відносно невеликих партій виробів. Комплекти ЗІП, які поставлялися разом 3 зазначеними виробами, не поповнювалися багато років, закупівля їх складових ускладнена через те, що такі зразки ЗРО, а відповідно й запасні частини знаходяться в Російській Федерації або країнах, лояльних до неї. Поступове вичерпання запасів з комплектів 3ІП засобів ЗРО обумовлює необхідність пошуку варіантів їх заміни. Крім того, елементна база суттєво еволюціонувала та змінила декілька поколінь. 
Отже, при вирішенні актуального наукового завдання потрібно врахувати, що модернізація ФС - це складний процес, який не має суворої математичної бази і ведеться методом чисельних проб і послідовних наближень. Тим не менш в ході цього процесу рішення багатьох проблем засноване на використанні математичних алгоритмів, розрахунків теплових режимів, міцності, допусків. Модернізація ФС засобів ЗРО може виконуватись за декількома альтернативними варіантами. Відмінність цих варіантів полягає в їх градації за рівнем глибини модернізації та використовуваної елементної бази, для чого в [6] запропоновано виділяти два рівня глибини модернізації ФС.

Під модернізацією ФС першого рівня розуміється заміна раніше встановлених в блоках (субблоках, модулях) ФС інтегральних мікросхем з малими ступенями інтеграції та інших дискретних елементів на HBIC зі збереженням типорозміру блоків (субблоків, модулів) ФС і всіх параметрів роз'ємів, за допомогою яких вони включаються в апаратуру більш високого рівня (наприклад, шафа, стійка). Здійснення модернізації ФС першого рівня може значно продовжити термін служби експлуатованих і морально не застарілих зразків ЗРО. Слід звернути увагу на той факт, що при здійсненні модернізації ФС першого рівня не потрібно дорогої переробки конструкції, кабельних розводок, інтерфейсу і відповідної документації виробів. У більшості випадків модернізація ФС першого рівня передбачає, що вся конструкція залишається існуючою, але замість великої кількості комплектуючих буде стояти один або кілька кристалів у вигляді великих інтегральних схем (BIC) чи НBIC. Іншими словами, нові комплектуючі, а саме спеціалізовані ВIC і HBIC, залишаються змонтованими в старі конструктиви (плати, блоки, стійки, шафи), причому площа цих конструктивів залишається практично не задіяною. В першу чергу підлягає модернізації апаратура, яка включає "проблемну" елементну базу, тобто морально застарілу елементну базу, випуск якої припинено або суттєво обмежено і в найближчому майбутньому буде припинений.

Перевагами проведення модернізації ФС першого рівня $\epsilon$ :

- заміна великої кількості комплектуючих на одну або кілька HBIC, що зменшує в сотні разів кількість роз'ємних з'єднань та призводить до суттєвого підвищення надійності апаратури;

- скорочення кількості мікросхем на платі до однієї або декількох ВІС або НBIC при використанні сучасних технологій їх проектування і виготовлення дозволяє, як мінімум, на порядок знизити споживану ними потужність;

- заміна великої кількості комплектуючих на одну-дві HBIC при незначному конструкторському доопрацюванні може значно зменшити масогабаритні характеристики апаратури;

- можливість повного збереження комутаційного інтерфейсу друкованої плати або іншого типового елемента заміни дозволяє здійснити заміну застарілої елементної бази на сучасну в максимально стислі терміни.

Для експлуатованих зразків озброєння модернізація ФС першого рівня дозволить:

- вирівняти диспропорцію морального старіння елементної бази апаратури та експлуатованого зразка озброєння;

- вирішити проблему модернізації апаратури зразків озброєння, пов'язану 3 удосконаленням алгоритмів обробки сигналів та інформації;

- вирішити проблему підтримки необхідних техніко-економічних і експлуатаційно-технічних характеристик (ETX) протягом всього терміну експлуатації;

- істотно спростити технічне обслуговування апаратури зразків озброєння;

- вирішити проблему формування та підтримки ЗІП в необхідних кількостях.

Очевидно, що будь-яка модернізація пов'язана 3 певними економічними 
витратами. Розрахунок сумарної вартості модернізації елементу ФС з використанням сучасної елементної бази $C_{\text {модг }}$ здійснюється за формулою

$$
\mathrm{C}_{\text {мод } \Sigma}=\mathrm{C}_{\text {розр }}+n \mathrm{C}_{\text {сер }}
$$

де $\mathrm{C}_{\text {розр }}$ - вартість розробки елементу ФС на сучасній елементній базі;

$\mathrm{C}_{\text {сер }}$ - вартість елементу ФС на сучасній елементній базі при серійному виробництві;

$n$ - кількість необхідних елементів ФС на сучасній елементній базі.

Розрахунок додаткових економічних витрат на модернізацію елементу ФС за 1-й рік $\Delta_{1}$ у порівнянні 3 витратами на підтримання елементу ФС до модернізації елементної бази в працездатному стані здійснюється за формулою

$$
\Delta_{1}=C_{\text {розр }}+n_{1}\left(C_{\text {сер }}+C_{\text {екс.м }}-\mathrm{C}_{\text {iсн }}\right) \text {, }
$$

де $\mathrm{C}_{\text {екс.м }}-$ середні річні витрати на підтримання елементу ФС на сучасній елементній базі в працездатному стані (обслуговування, ремонт, тощо);

$\mathrm{C}_{\text {існ }}$ - середні річні витрати на підтримання елементу ФС до модернізації елементної бази в працездатному стані (обслуговування, ремонт, тощо);

$n_{1}$ - кількість елементів ФС на сучасній елементній базі, виготовлених та введених в експлуатацію протягом 1-го року.

Розрахунок додаткових економічних витрат на модернізацію елементу ФС за наступний $k$-й рік $\Delta_{k}$ у порівнянні з витратами на підтримання елементу ФС до модернізації елементної бази в працездатному стані здійснюється за формулою

$$
\begin{aligned}
\Delta_{k}=\sum_{i=1}^{k-1} n_{i} & \left(C_{\text {екс.м }}-\mathrm{C}_{\mathrm{icн}}\right)+n_{k}\left(C_{\text {сер }}+\right. \\
+ & \left.C_{\text {екс.м }}-\mathrm{C}_{\text {iсн }}\right),
\end{aligned}
$$

де $n_{\mathrm{i}}$ - кількість елементів ФС на сучасній елементній базі, виготовлених та введених в експлуатацію протягом i-го року;

$n_{k}$ - кількість елементів ФС на сучасній елементній базі, виготовлених та введених в експлуатацію протягом $k$-го року;

Відчутним недоліком модернізації ФС першого рівня $\epsilon$ те, що модернізована апаратура (сучасні BIC і HBIC) залишаються в оточенні старих конструктивів (плат, блоків, стійок, шаф), причому площа цих конструктивів тепер буде практично не задіяна. Саме цей факт в подальшому обумовлює необхідність розгляду зміни конструкції радіоелектронної апаратури (замінити блок на плату, шафу на блок, а, можливо, і шафу на плату) за рахунок проведення більш глибокої модернізації, яка може базуватися й на результатах модернізації ФС першого рівня. Використання більш глибокої інтеграції елементів при модернізації апаратури може якісно змінити наповнення модернізованих зразків озброєння при істотному поліпшенні їх тактико-технічних характеристик (ТTX). Така більш глибока модернізація має інший рівень, тому це $\epsilon$ модернізація ФС другого рівня. Характерним моментом здійснення модернізації ФС другого рівня може бути те, що вона не потребуватиме великих капіталовкладень і часових витрат, якщо будуть повністю використовуватися результати проведення попередньої “латентної" модернізації, протягом якої вже відпрацьовуватиметься заміна комплектуючих, реалізованих на застарілій елементній базі. Для модернізованих систем озброєння модернізація елементної бази, i зокрема модернізація другого рівня, може істотно змінити вигляд системи озброєння і привести до створення абсолютно нового за своїми ТТХ зразка озброєння. Іншими словами, з'являється можливість еволюційним шляхом створити новий зразок озброєння, який за своїми ТТХ істотно перевершуватиме базовий.

Однак реалізація вищезазначених варіантів модернізації ФС неодмінно буде ускладненою, оскільки в Україні майже не виробляються сучасні цифрові компоненти та радіоелементи. Це обумовлює той факт, що 
модернізація функціональних систем (блоків, субблоків) зразків ЗРО та їх складових частин повинна буде здійснюватися за рахунок імпортованих цифрових компонентів та радіоелементів. 3 урахуванням збройного конфлікту на сході України відкрите постачання іншими країнами 3 метою створення або модернізації зразків ЗРО елементів категорії "military" майже неможливе, а елементів категорії "indusrial" суттєво обмежується. На елементи категорії "commertial", як правило, обмеження не накладаються. Слід зазначити, що технічні характеристики елементів всіх зазначених категорій здебільшого співпадають, а якщо й різняться (не завжди), то, як правило, надійністю та працездатністю в екстремальних умовах.

Тому в умовах, що склалися, доцільною $\epsilon$ розробка модернізованих систем (блоків, субблоків) зразків ЗРО та їх складових частин на базі імпортованих елементів 3 урахуванням додаткових організаційних та технічних заходів щодо забезпечення надійності у визначених умовах експлуатації. До організаційних заходів можна віднести проведення додаткового тестування закуплених елементів категорій "indusrial" та "commertial” в різних умовах, наближених до граничних умов експлуатації, 3 відбракуванням тих, що не пройшли випробування $[15,16]$. До технічних заходів можна віднести проектування в складі модернізованих систем (блоків, субблоків) модулів 3 додатковими пристроями температурної стабілізації та віброгасіння.

Обґрунтування доцільного варіанту модернізації ФС зразків ЗРО з декількох альтернативних як за рівнем глибини модернізації, так за використовуваною елементною базою потребує розробки чіткого методичного апарату, в якості якого й виступатиме запропонований методичний підхід до обґрунтування раціонального варіанту модернізації ФС зі створенням їх елементів на сучасній елементній базі. Блоксхема даного методичного підходу наведена на рис.1 і містить наступні етапи:

- формування технічного завдання ;

- аналіз вихідних даних та формування основних технічних вимог до конструкції елементу ФС на сучасній елементній базі;

- вибір та обґрунтування елементної бази, уніфікованих вузлів, комплектуючих виробів та матеріалів конструкції створюваного елементу ФС на сучасній елементній базі;

- вибір та обґрунтування схеми компонування, методів і принципів конструювання створюваного елементу ФС на сучасній елементній базі;

- вибір способів і засобів теплозахисту, герметизації, віброзахисту та екранування створюваного елементу ФС на сучасній елементній базі;

- розрахунок конструктивних параметрів створюваного елементу ФС на сучасній елементній базі;

- аналіз і врахування вимог ергономіки та технічної естетики (при необхідності);

- обґрунтування заходів щодо захисту від корозії, вологи, електричних ударів, електромагнітних полів та механічних навантажень;

- визначення раціонального варіанту створення елементу ФС на сучасній елементів базі.

Перші два етапи виконуються одноразово для конкретного типу елементу ФС. В ході третього етапу формуються декілька (в загальному випадку) альтернативних варіантів створення елементу ФС 3 використанням різних елементів сучасної елементної бази. 


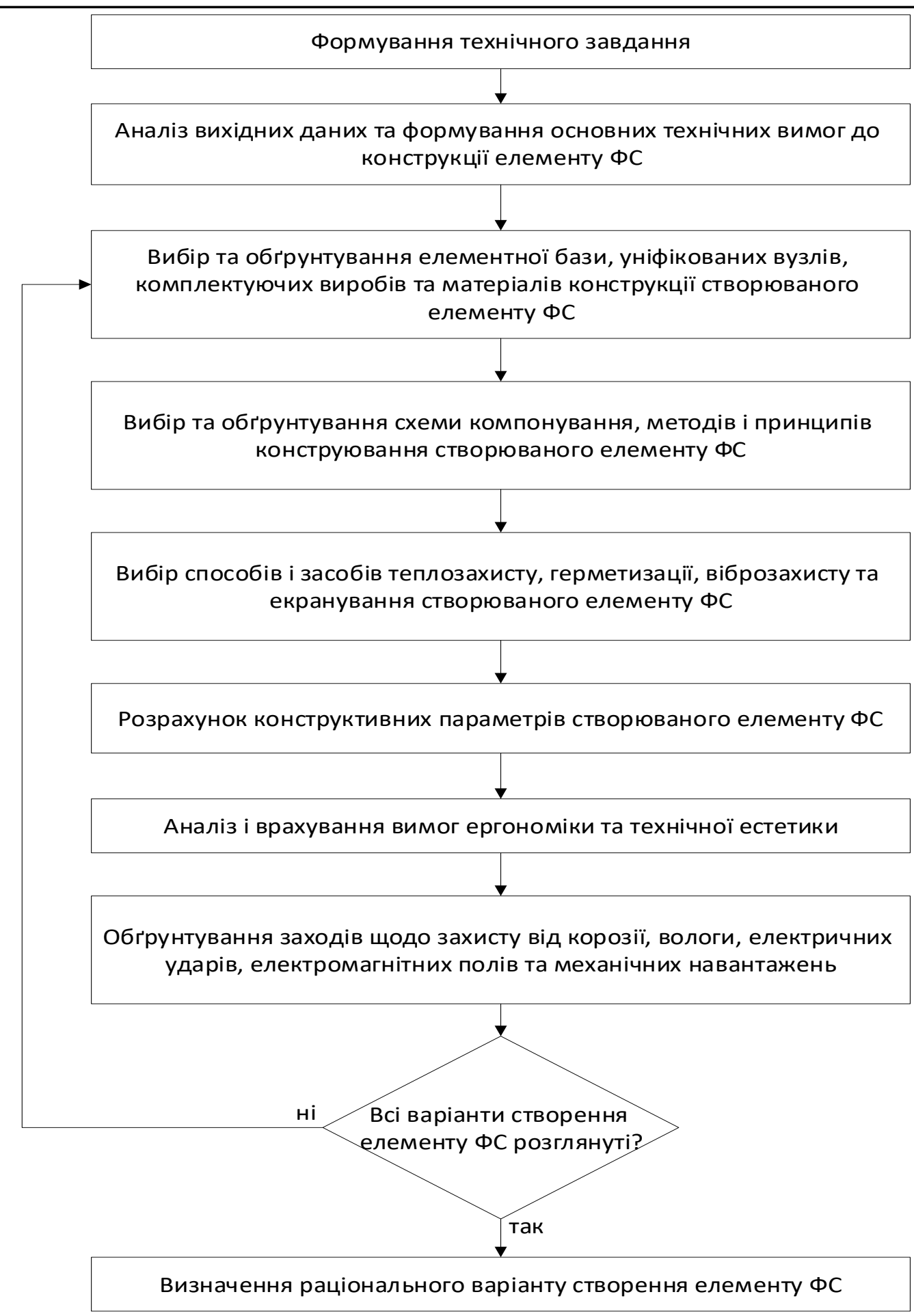

Рисунок 1 - Блок-схема методичного підходу до обґрунтування раціонального варіанту модернізації ФС на сучасній елементній базі

Наступні етапи (крім останнього) завершальним і дає обґрунтовану представляють собою ітераційну процедуру, рекомендацію щодо найбільш доцільного яка виконується послідовно для кожного варіанту створення елементу ФС на сучасній варіанту побудови елементу ФС на сучасній елементній базі.

елементній базі. Останній етап $\epsilon$




\section{Висновки}

Таким чином, в статті наведений методичний підхід щодо обґрунтування раціонального варіанта модернізації ЗРО 3 урахуванням зміни властивостей елементів радіоелектронної апаратури і можливостей щодо створення елементів ФС на сучасній елементній базі.

Реалізація наведених пропозицій щодо використання сучасної елементної бази при модернізації функціональних систем (блоків, субблоків) зразків ЗРО дозволить:

- відновити запаси комплектів зІП та зменшити номенклатуру їх елементів за рахунок використання в різних блоках однотипного апаратного забезпечення 3 різним програмним (комп'ютерні модулі, мікроконтролерні модулі, тощо);

- зменшити кількість настроювань, регулювань блоків за рахунок переходу до апаратних рішень на базі цифрової техніки, що скоротить кількість операцій при проведенні технічних обслуговувань і, як наслідок, тривалість їх проведення;

- забезпечити необхідний рівень надійності виробів (покращення безвідмовності блоків за рахунок високої безвідмовності сучасних цифрових пристроїв у порівнянні з відповідними штатними блоками зразків ЗРО, покращення ремонтопридатності за рахунок поповнення запасів комплектів зІП та зменшення тривалості робіт з заміни несправних модулів).

Напрямами подальших досліджень $\epsilon$ обґрунтування та вибір показників та критерію ефективності, використання яких дозволить описати кожен 3 варіантів модернізації зі створенням елементу ФС на сучасній елементній базі, в тому числі матеріальні та часові витрати, та порівняти їх між собою.

\section{Список використаних джерел}

1. Коровин А. Н. Ракетные комплексы ПВО: тенденции развития. [Електронний ресурc]. URL: https://topwar.ru/2217raketnye-kompleksy-pvo-tendenciirazvitiya.html

2. Гриб Д. А. Концептуальные подходы к развитию и поддержанию в боеготовом состоянии зенитного ракетного вооружения Воздушных Сил ВСУ на период до 2025 года/ Д.А. Гриб, Б.Н. Ланецкий, В.В. Лукьянчук, И. М. Николаев. // Збірник наукових праць ХУПС, 2010, випуск 15. - С. 20-36.

3. Карпенко Д. В. Стан та перспективи розвитку зенітного ракетного озброєння Повітряних Сил Збройних Сил України. // Наука і техніка Повітряних Сил Збройних Сил України, 2017, випуск 2(27). - С. 75-78.

4. Митчелл Р. Моральный износ и как с ним бороться [Електронний ресурс]. Computer world Россия, 2008, випуск 32. URL: https://www.osp.ru/cw/2008/32/5462756/
5. Ланецкий Б. Н., Лукьянчук В.В., Артеменко А.А. (2016). Комплексное оценивание показателей безотказности и остаточной долговечности сложных технических систем, эксплуатируемых по техническому состоянию. Основные положення. Системи обробки інформації. Випуск 2 (139).- С. 40-43.

6. Лазаревич Э. Г., Колганов С. К., Алдошин В. М. (2006). Виртуальная элементная база новая концептуальная основа обеспечения модернизации и создания перспективных образцов вооружения. Наука и военная безопасность, 2006, Випуск 3. - С. 21-25.

7. Рябинин И. А. (2003). Логиковероятностное исчисление как аппарат исследования надежности и безопасности структурно-сложных систем. Автоматика и телемеханика, 2003, Выпуск 7.- С. 178186.

8. Picardi C. Model synthesis for model-based 
fault analysis. / C. Picardi, L. Console, D. Th. Dupre // In Proceedings of the 15th International Workshop on Principles of Diagnosis, Carcassonne, 2004.

9. Зеленцов В. А., Миронов А. Н., Прохорович В. Е. (2000). Прогнозирование показателей долговечности стартовых комплексов на основе интегрированных структурных моделей предельного состояния [Електронний ресурс]. Двойные технологии, Випуск 1. - С. 23-25. URL: http://www.sipria.ru/dt20_01.html

10. Шестопалова О.Л., Муравьев А. В. Прогнозирование срока службы информационной системы с учетом морального старения элементной базы технических средств [Електронний ресурс]. Транспортное дело России, 2014, випуск №6. - С. 186-189.

11. Шестопалова О.Л. (2007). Управление развитием информационных систем с учетом мониторинга морального старения [Електронний ресурс]. Современные наукоемкие технологии, Випуск 6. - С. 103-107. URL: http://www.toptechnologies.ru/ru/article/view?id=36707.

12. Гузенко В. Л., Клепов А. В., Миронов А. Н., Шестопалова О.Л. (2014). Постановка задачи обеспечения техникоэкономической эффективности эксплуатации распределенной информационной системы [Електронний ресурс]. Современные проблемы науки и образования, Випуск 2. URL: https://science-

education.ru/ru/article/view?id=12361.

13. Миронов А.Н., Новиков А.Н., Малахов А.В. (2016). Индивидуально-групповое прогнозирование остаточного ресурса измерительных комплексов по экономическому критерию [Електронний ресурс]. Наукоемкие технологии 8 космических исследованиях Земли, Т. 8, випуск 4. - С. 25-30. URL: http://www.hes.ru/ru/citation-ru/2016.html.

14. Lukyanchuk, V., Nikolaev, I., Tkachev, V., Open'koP., \& Drannyk, P. (2020). Methodical approach to the choice of a rational option maintainability of an anti-aircraft missile system in the conditions of moral aging of the third general. Journal of Scientific Papers "Social Development and Security», 10(3), 315. DOI: $10.33445 /$ sds.2020.10.3.1

15. Ніколаєв І.М. (2018). Пропозиції щодо порядку використання іноземної елементної компонентної бази в радіоелектронній апаратурі зенітного ракетного озброєння, за яким не здійснюється авторський нагляд. Озброєння та військова техніка, Випуск 1(17). - С. 32-37.

16. Чепков І. Б., Ланецький Б.М., Лук'янчук В.В., Ніколаєв І.М. (2012). Механізм заміни комплектуючих виробів озброєння та військової техніки сучасними аналогами нової техніки. Наука і оборона, Випуск 2. C. 54-60.

\section{Методический подход к определению рационального варианта модернизации функциональных систем образцов зенитного ракетного вооружения}

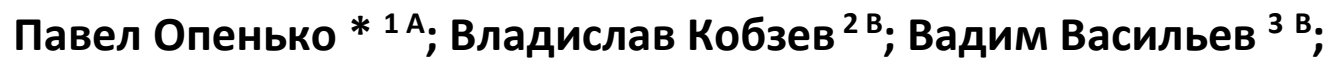
Олег Угринович ${ }^{4}$ А; Владимир Дяченко ${ }^{5 ~ C}$

* Corresponding author: ${ }^{1}$ к.тех.н., старший исследователь, начальник научно-исследовательского отдела, e-mail: pavel.openko@ukr.net, ORCID: 0000-0001-7777-5101

2 к.т.н., с.н.с., старший научный сотрудник научно-исследовательского отдела, e-mail: vladiskob@ukr.net, ORCID: 0000-0002-0954-8887

${ }^{3}$ к.т.н., с.н.с., старший научный сотрудник научно-исследовательского отдела, e-mail: vva74@ukr.net, ORCID: 0000-0001-5802-9111

${ }_{4}^{4}$ к.в.н., доцент, профессор кафедры, e-mail: olegenya999@gmail.com, ORCID: 0000-0001-6644-7620

${ }^{5}$ к.в.н., начальник кафедры, e-mail: gw7388@gmail.com, ORCID: 0000-0002-2904-8337

А Национальный университет обороны Украины имени Ивана Черняховского, г. Киев, Украина
} 


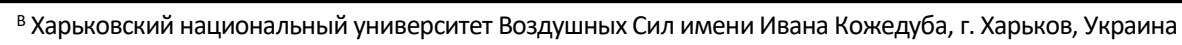

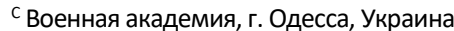

\title{
Аннотация
}

Результаты исследований, опубликованные в статье, будут полезны для специалистов логистического обеспечения, занимающихся вопросами организации эксплуатации и восстановления вооружения и военной техники. В статье рассматривается методический подход к обоснованию рационального варианта модернизации зенитного ракетного вооружения с учетом изменения свойств элементов радиоэлектронной аппаратуры и возможностей создания элементов функциональных систем на современной элементной базе. Проанализированы существующие в научно-технической литературе публикации, посвященные вопросам морального старения сложных технических систем разного назначения, в том числе состояния элементной базы радиоэлектронной аппаратуры образцов зенитного ракетного вооружения, установлено, что задачи, связанные с модернизацией функциональных систем образцов зенитного ракетного вооружения, с изменением свойств элементов оборудования, используя при этом современную элементную базу, в настоящее время является нерешенным, что позволило сформулировать научную задачу, заключающуюся в дальнейшем развитии научнометодического аппарата выбора рационального варианта модернизации зенитного ракетного вооружения с учетом изменения свойств элементов радиоэлектронной аппаратуры и возможностей создание функциональных систем на современной элементной базе.

Обоснован выбор целесообразного варианта модернизации функциональных систем образцов зенитного ракетного вооружения из нескольких альтернативных как по уровню глубины модернизации, так и по используемой элементной базе с использованием методического аппарата, в качестве которого будет выступать предложенный методический подход к обоснованию рационального варианта модернизации функциональных систем с созданием их элементов на современной элементной базе. Показано, что в сложившихся условиях целесообразна разработка модернизированных систем (блоков, субблоков) образцов зенитного ракетного вооружения и их составных частей на базе импортируемых элементов с учетом дополнительных организационных и технических мер по обеспечению надежности в определенных условиях эксплуатации. Представлено, что для решения поставленной задачи требуется обоснование и выбор показателей и критерия эффективности, использование которых позволит описать каждый из вариантов модернизации с созданием элемента функциональных систем на современной элементной базе, в том числе материальные и временные затраты, и сравнить их между собой.

Ключевые слова: зенитное ракетное вооружение, моральное старение, функциональная система, элементная база, модернизация.

\section{Methodical approach to determining a rational option for modernization of anti-aircraft missile weapons' functional systems}

\author{
Pavlo Open'ko * 1A; Vladislav Kobzev 2B; Vadym Vasiliev ${ }^{3 \text { B; }}$ \\ Oleh Uhrynovych ${ }^{4}$; ; Volodymyr Diachenko ${ }^{5 \mathrm{C}}$ \\ * Corresponding author: ${ }^{1}$ Candidate of Technical Science, Senior Researcher, Head of the Scientific-research Department, e-mail: \\ pavel.openko@ukr.net, ORCID: 0000-0001-7777-5101 \\ ${ }^{2}$ Candidate of Technical Science, Senior Researcher, Senior Researcher of the Scientific-research Department, e-mail: vladiskob@ukr.net, \\ ORCID: 0000-0002-0954-8887 \\ ${ }^{3}$ Candidate of Technical Science, Senior Researcher, Senior Researcher of the Scientific-research Department, e-mail: vva74@ukr.net, \\ ORCID: 0000-0001-5802-9111
}


${ }^{4}$ Candidate of Military Sciences, Associate Professor, Professor of the Department, e-mail: olegenya999@gmail.com, ORCID: 0000-0001-6644-7620

${ }^{5}$ Candidate of Military Sciences, Head of the Department, e-mail: gw7388@gmail.com, ORCID: 0000-0002-2904-8337

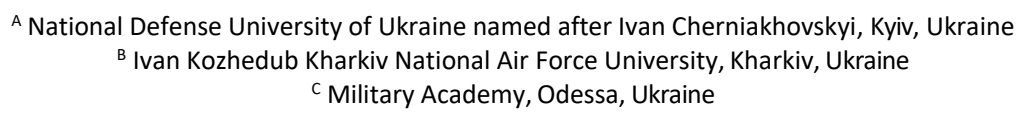

\begin{abstract}
The results of the research published in the article will be useful for logistic support specialists who are involved in the organization of the operation and renewal of weapons and military equipment. The article discusses the methodical approach to substantiate the rational option of modernization of anti-aircraft missile weapons, taking into account changes in the properties of elements of electronic equipment and opportunities to create elements of functional systems on a modern element base. The publications in the scientific and technical literature on the issues of the aging of complex technical systems for various purposes, including the state of the element base of electronic equipment of anti-aircraft missile weapons, found that tasks related to the modernization of functional anti-aircraft missile systems, changes in the properties of equipment elements, using a modern element base, is currently unsolved, which allowed to determine the scientific task of further development of the scientific and methodological approach of choosing a rational option for modernization of anti-aircraft missile systems, taking into account changes in the properties of electronic equipment creation of elements of functional systems on a modern element base.

The choice of the expedient variant of modernization of functional systems of antiaircraft missile armament samples from several alternative both on level of depth of modernization, and on the used element base on use of the methodical device as the offered methodical approach to substantiation of rational variant of systems on modernization of their functions element base. It is shown that in the current conditions, it is advisable to develop modernized systems (units, subunits) of anti-aircraft missile weapons and their components based on imported elements, taking into account additional organizational and technical measures to ensure reliability in certain operating conditions. It is stated that to solve this problem requires justification and selection of indicators and performance criteria, the use of which will describe each of the options for modernization with the creation of an element of functional systems on a modern element base, including material and time costs, and compare them.
\end{abstract}

Keywords: anti-aircraft missile weapons, moral aging, functional system, element base, modernization.

\title{
References
}

1. Korovin A. "Raketnyye kompleksy PVO: tendentsii razvitiya" [Missile defense systems: development trends], Available from: https://topwar.ru/2217-raketnyekompleksy-pvo-tendencii-razvitiya.html.

2. Grib D., Lanetskiy B., Luk'yanchuk V., Nikolaev I. (2010). Kontseptual'nyye podkhody k razvitiyu i podderzhaniyu $\mathrm{v}$ boyegotovom sostoyanii zenitnogo raketnogo vooruzheniya Vozdushnykh Sil VSU na period do 2025 goda" [Conceptual approaches to the development and combat readiness of anti-aircraft missile weapons of the Air Force of the Armed Forces for the period until 2025]. Collection of scientific papers, KHUPS,
No 15 , pp. 20-36.

3. Karpenko D. (2017). "Stan ta perspektyvy rozvytku zenitnoho raketnoho ozbroyennya Povitryanykh Syl Zbroynykh Syl Ukrayiny" [State and prospects of development of air defense missiles of the Ukrainian Armed Forces]. Science and Technology of the Air Force of the Armed Forces of Ukraine, No.2 (27), pp.75-78, Available from: https://www.ukrmilitary.com/2017/05/state -amd-perspectives-of-development-of-antiaircraft-missile-armament.html.

4. Mitchell R. (2008). "Moral'nyy iznos i kak s nim borot'sya" [Moral depreciation and how to deal with it]. Computer world Russia, No. 


\section{2, Available from:} https://www.osp.ru/cw/2008/32/5462756/.

5. Lanetskiy B., Luk'yanchuk V., Artemenko A. (2016). "Kompleksnoye otsenivaniye pokazateley bezotkaznosti i ostatochnoy dolgovechnosti slozhnykh tekhnicheskikh sistem, ekspluatiruyemykh po tekhnicheskomu sostoyaniyu. Osnovnyye polozhennya" [Comprehensive assessment of reliability and residual durability of complex technical systems operated by technical condition. The main provisions], Information Processing Systems, issue 2 (139), pp. 40-43.

6. Lazarevich, E., Kolganov, S., Aldoshin, V. (2006). "Virtualnaya elementnaya baza novaya kontseptualnaya osnova obespecheniya modernizatsii i sozdaniya perspektivnyih obraztsov vooruzheniya" [The virtual element base is a new conceptual basis for ensuring the modernization and creation of promising weapons models.] Science and Military Security, No 3, pp. 21-25.

7. Ryabinin I. (2003). "Logiko-veroyatnostnoye ischisleniye kak apparat issledovaniya nadezhnosti i bezopasnosti strukturnoslozhnykh sistem" [Logic-probabilistic calculus as an apparatus for studying the reliability and safety of structurally complex systems]. Automation and Telemechanics, Issue 7, pp. 178-186, Available from: http://www.mathnet.ru/php/archive.phtml? wshow=paper\&jrnid=at\&paperid=1918\&opti on_lang=rus

8. Picardi C. (2004). Model synthesis for modelbased fault analysis. / C. Picardi, L. Console, D. Th. Dupre // In Proceedings of the 15th International Workshop on Principles of Diagnosis. / Carcassonne.

9. Zelentsov V., Mironov A., Prokhorovich V. (2000) "Prognozirovaniye pokazateley dolgovechnosti startovykh kompleksov na osnove integrirovannykh strukturnykh modeley predel'nogo sostoyaniya" [Prediction of durability indicators of launch complexes based on integrated structural models of the limiting state], Dual
Technologies, No. 1. pp. $23-25$, Available from: http://www.sipria.ru/dt20_01.html http://www.sipria.ru/dt20_01.html/

10. Shestopalova O., Murav'ev A. (2014) "Prognozirovaniye sroka sluzhby informatsionnoy sistemy $s$ uchetom moral'nogo stareniya elementnoy bazy tekhnicheskikh sredstv" [Predicting the life of an information system, taking into account the moral aging of the hardware components base], Transport business of Russia, No. 6, pp. 186-189.

11. Shestopalova O. (2017) "Upravleniye razvitiyem informatsionnykh sistem $s$ uchetom monitoringa moral'nogo stareniya" [Management of the development of information systems taking into account monitoring of moral aging], Modern high technology, No. 6, pp. 103-107, Available from: http://www.toptechnologies.ru/ru/article/view?id=36707.

12. Guzenko V., Klepov A., Mironov E., Shestopalova O. (2014). "Postanovka zadachi obespecheniya tekhniko-ekonomicheskoy effektivnosti ekspluatatsii raspredelennoy informatsionnoy sistemy" [Statement of the problem of ensuring technical and economic efficiency of the operation of a distributed information system], Modern problems of science and education, No.2, Available from: https://science-education.ru/ru/article/ view ?id=12361.

13. Mironov A., Novikov A., Malakhov A. (2016) "Individual'no-gruppovoye prognozirovaniye ostatochnogo resursa izmeritel'nykh kompleksov po ekonomicheskomu kriteriyu" [Individual-group forecasting of the residual life of measuring systems by the economic criterion], High technology in space exploration of the Earth, Vol. 8, No. 4, pp. 2530, Available from: http://www.hes.ru/ru/citation-ru/2016.html.

14. Luk'yanchuk, V., Nikolaev, I., Tkachev, V., Open'ko, P., \& Drannyk, P. (2020). Methodical approach to the choice of a rational option maintainability of an antiaircraft missile system in the conditions of 
moral aging of the third general. Journal of Scientific Papers "Social Development and Security», No 10(3), pp. 3-15. DOI: 10.33445/sds.2020.10.3.1.

15. Nikolaev, I. (2018). "Propozitsiyi schodo poryadku vikoristannya inozemnoyi elementnoyi komponentnoyi bazi $v$ radioelektronniy aparaturi zenitnogo raketnogo ozbroennya, za yakim ne zdiysnyuetsya avtorskiy naglyad" [Proposals on the use of foreign elemental component base in the electronic equipment of anti- aircraft missile weapons, which is not subject to author's supervision.], Armament and military equipment. No 1 (17), pp. 32-37.

16. Chepkov, I., Lanetsky, B., Luk'yanchuk, V., Nikolaev, I. (2012). "Mehanizm zamini komplektuyuchih virobiv ozbroennya ta viyskovoyi tehniki suchasnimi analogami novoyi tehniki" [The mechanism of replacement of components of armaments and military equipment with modern analogues of new equipment.] Science and Defense, No 2, pp. 54-60. 